Pesq. Vet. Bras. 37(9):905-910, setembro 2017 DOI: $10.1590 / \mathrm{S} 0100-736 \mathrm{X} 2017000900001$

\title{
Prevalence and risk factors for porcine cysticercosis in rural communities of eastern Minas Gerais, Brazil ${ }^{1}$
}

\author{
Emilio C. Acevedo-Nieto ${ }^{2 *}$, Paulo S.A. Pinto ${ }^{2}$, Letícia F. Silva², Rafaella P.M. Guimarães- \\ Peixoto ${ }^{2}$, Tatiane 0. Santos ${ }^{2}$, Camilla T.S. Ducas ${ }^{2}$ and Paula D. Bevilacqua ${ }^{2}$
}

\begin{abstract}
Acevedo-Nieto E.C., Pinto P.S.A., Silva L.F., Guimarães-Peixoto R.P.M., Santos T.O., Ducas C.T.S. \& Bevilacqua P.D. 2017. Prevalence and risk factors for porcine cysticercosis in rural communities of eastern Minas Gerais, Brazil. Pesquisa Veterinária Brasileira 37(9):905-910. Setor de Medicina Veterinária Preventiva, Departamento de Veterinária, Universidade Federal de Viçosa, Avenida PH Rolfs s/n. Viçosa, MG 36570-900, Brazil. E-mail: ecanieto@gmail.com
\end{abstract}

Cysticercosis is caused by Taenia solium, a parasitic zoonosis that affects human and pigs raised free-range in developing countries. The epidemiology of the taeniosis cysticercosis complex in Brazil is poorly understood especially when it comes to field research. The aim of this study was to estimate the prevalence and identify the risk factors associated with porcine cysticercosis in rural communities located in the east of Minas Gerais (MG), Brazil. From 371 farms in the county of Tumiritinga/MG, 101 farms from 14 communities were randomly sampled. Blood samples from pigs were collected, and epidemiological questionnaires were carried out. The serum samples obtained were analyzed through immunodiagnosis techniques, including ELISA and Western Blot, both for the detection of antibodies. The data obtained by different surveys were analyzed using EpiInfo 3.5.1 software to determine seroprevalence and risk factors associated with cysticercosis. The prevalence of farms with porcine cysticercosis was 9.9\% (10/101) and antibody-based seropositive was $5.3 \%(13 / 247)$. The results indicate that cysticercosis occurs in high level in the rural area never studied before. These results suggest the presence of tapeworm carriers contributing to the occurrence and maintenance of this zoonotic life cycle in the county. Regarding risk factors, the most significant determinants for porcine cysticercosis in the field were free-range pig management (OR: 17.4, p: 0.0001), the method of disposal of human faeces in the environmental (OR: 7.6; p 0.012), and the size of the farm. Porcine cysticercosis was diagnosed only in areas represented by Agrarian Reform Settlements. From the results, it is possible to recommend as a means of control and prevention the destination of human faeces in appropriate sanitary landfills and the production of pigs in an enclosed area. Additionally, improving education in the communities sampled will indirectly affect the spreading of this disease. The results draw attention to the largest studies of this zoonotic disease in human settlements from rural areas due to the lack of knowledge about the epidemiology of the taeniosis-cysticercosis complex. The results could serve as the basis to support public policies aimed at creating an effective program to control the taeniosis-cysticercosis complex in the studied area. Awareness of TC among medical doctors, veterinarians, meat animal family producers and the public should be developed through appropriate information and education.

INDEX TERMS: Cysticercosis, swine, risk factors, seroprevalence, Taenia solium, taeniasis, zoonosis.

\footnotetext{
${ }^{1}$ Received on August 16, 2015

Accept for publication on October 21, 2016

${ }^{2}$ Laboratório de Inspeção de Produtos de Origem Animal, Departamento de Veterinária, Universidade Federal de Viçosa (UFV), Avenida Peter Henry Rolfs s/n. Viçosa, MG 36570-900, Brazil. *Corresponding author: ecanieto@gmail.com
}

RESUMO.- [Prevalência e fatores de risco para cisticercose suína em comunidades rurais do leste de Minas Gerais.] A cisticercose causada pela Taenia solium é uma zoonose parasitária que afeta humanos e suínos principalmente nos países em desenvolvimento. No 
Brasil, sua epidemiologia é ainda pouco compreendida em diversas regiões. 0 objetivo deste estudo foi estimar a prevalência e identificar os fatores de risco associados à cisticercose suína em comunidades rurais localizadas na região leste do estado de Minas Gerais (MG). A partir de 371 propriedades pertencentes à 14 comunidades rurais do município de Tumiritinga, 101 foram amostradas aleatoriamente. Foram coletadas amostras de sangue dos suínos e aplicados questionários epidemiológicos. As amostras séricas foram analisadas através de técnicas de imunodiagnóstico, ELISA e Western Blot, para a detecção de anticorpos. Os dados obtidos nos inquéritos foram analisados utilizando o software EpiInfo 3.5.1 para determinar os fatores de risco associados à cisticercose. A prevalência das propriedades com a presença da cisticercose suína foi de 9,9\% (10/101), a soropositividade foi de 5,3\% (13/247). Os resultados são alarmantes para a ocorrência da cisticercose suína, sugerindo a presença de portadores de tênia que contribuem manutenção deste ciclo zoonótico nas áreas amostradas. Em relação aos fatores de risco, os determinantes mais importantes para a ocorrência da cisticercose suína foram a criação de suínos soltos (OR:17,4, p:0,0001), a eliminação de fezes humanas no meio ambiente (OR:7,6, p:0,012 ) e o tamanho da propriedade. Cisticercose suína foi diagnosticada somente em áreas representadas por assentamentos de Reforma Agrária. Os resultados permitem recomendar como medida de controle, a destinação dos dejetos humanos em sistemas adequados, a utilização de fossas sépticas, a criação de suínos em sistemas confinados e investimentos em educação em saúde. Ainda, os resultados chamam a atenção para maiores estudos sobre esta zoonose nos assentamentos da reforma agrária do país, devido à sua presença e à falta de conhecimento sobre a epidemiologia da teníase-cisticercose nestas áreas. Estas informações podem servir de base para apoiar políticas públicas voltadas para a criação de um programa eficaz de controle da teníase-cisticercose na região estudada. Uma maior atenção para esta zoonose deve ser estimulada entre médicos, médicos veterinários e agricultores familiares, através da informação e educação.

TERMOS DE INDEXAÇÃO: Cisticercose suína, fatores de risco, soroprevalência, Taenia solium, taeniose, zoonose.

\section{INTRODUCTION}

The taeniosis-cysticercosis complex (TC) is a zoonotic disease shared between humans and pigs and consists of a disease perpetuated by different biological forms of the helminth parasite Taenia solium infections (Garcia \& Del Brutto 2000). Pigs are the intermediate host and who are infected by ingestion of infective eggs and/or proglottids that develop into cysticerci causing porcine cysticercosis. This is one of the most important zoonotic disease caused by a helminth parasite worldwide (Gonzalez et al. 2006). It constitutes a serious public health problem, especially in developing countries, where there are still a lack of sanitary facilities and socio-economic factors that contribute to the maintenance of the parasite's life cycle (Phiri et al. 2003). Humans can act as intermediate hosts as well and cysts can develop subcutaneously, intramuscularly, and often in the central nervous system causing neurocysticercosi (NCC) (Torgerson \& Macpherson 2011). Currently, it is one of the most important parasitic zoonosis that affects the central nervous system in humans worldwide (Deckers \& Dorny 2010, Ndimubanzi et al. 2010). The disease can cause epilepsy. The global burden of epilepsy was estimated at 7.8 million with 6.5 million of these occurring in T. solium endemic regions of the world (Torgerson \& Macpherson, 2011). There are at least 2.5 million carriers of taeniosis in the world, distributed mainly in Latin America, India and the African continent. The prevalence of the TC complex in Brazil is often underestimated due the lack of epidemiological studies and the absence of mandatory reporting in many regions. Therefore, the epidemiological situation is still unclear. It is known that the TC complex occurs in different Brazilian regions and is more frequent in economically poorer regions.

In Brazil, data on porcine cysticercosis are outdated and do not reflect the current Brazilian scenario as most of them come from surveys conducted in slaughterhouses under Federal Inspection Service. The prevalence register of cysticercosis in indoor porcine breeding farms is very low. The state of Santa Catarina, a pioneer in this type of animal farming, has recorded prevalence rates in the order of $0.002 \%$. These values do not accurately reflect the prevalence of TC in pigs reared in a free-range environment, where the prevalence can be much higher (Pinto et al. 2002). Results from field study researches are still scarce in this country (Ferreira et al. 2012). In several regions of the country, mainly in small counties, there is no inspection of pork prior to human consumption and much of the pork comes from small farms with limited technology (Iasbik et al. 2010).

The improvement of immunodiagnostic techniques has resulted in a practical and efficient alternative for the diagnosis of porcine cysticercosis (Flisser \& Gyorkos 2007). The ELISA and Immunoblot tests have been applied to determine the epidemiological profile of the TC complex (Santos et al. 2013, Silva et al. 2015). Records of the occurrence of the TC complex promote streamlined control measures and the use of questionnaires is an important tool for identifying risk factors (Souza et al. 2013). When combined, the results of immunodiagnostic tests with those from the questionnaires provide knowledge of the disease epidemiology, thus directing the appropriate measures for its prevention and control (Pondja et al. 2010).

The clarification of the epidemiology of cysticercosis can provide robust evidence to justify the implementation of public policies for the prevention and control of the TC complex in a region. This study aimed at evaluating the epidemiological profile of porcine cysticercosis in rural communities in the county of Tumiritinga located in the east of Minas Gerais State, Brazil. In addition, we sought to contribute to the improvement of public sanitation in the county by directing actions at the prevention and control of cysticercosis. 


\section{MATERIALS AND METHODS}

Study area. This study was developed in Tumiritinga County located in the Rio Doce Valley in the east of Minas Gerais State, Brazil. It has an area of 497 square kilometres, with a total population of 5.964 people (IBGE 2008) and 371 rural farms (IMA 2010, INCRA 2010) distributed in 14 rural communities. A percentage of $26 \%$ of the total population live in rural areas and $74 \%$ live in urban areas. Much of the rural area were made up of large farms and some of which were developed during the last years in Agrarian Reform settlements and are home to approximately 200 families of settlers. The settlement consists in several smalls properties called Family Production Unit (FPU). Local commerce is made up of small retail establishments that are primarily fuelled by the products of family farming (meat, dairy products, vegetables, fruits, grains, bread and pastries), mostly from the settlements. These products are an important source of income and employment in the county and strengthen local trade significantly. The county has no slaughterhouses and individual farms are not regulated in terms of slaughter and distribution, thus the meat provided to the county has no oversight by health inspectors.

Study design and sample size. A cross-sectional serological survey was undertaken to estimate seroprevalence of porcine cysticercosis and identify risk factors for Taenia solium transmission. The sample size was calculated from the total number of 222 farms, just those farms with pig production. The survey was conducted in 14 rural communities (Table 1). The sample unit number was performed using software EpiInfo 3.5.1 (CDC 2008), considering a range of $95 \%$ and an expected frequency of porcine cysticercosis of $2.44 \%$. This frequency was the result of a prior evaluation in census form that had been held in one of the fifteen rural communities of the county. Thus, the sample size obtained was 101 farms that were selected randomly through the same software. All of the farms were georeferenced (GPS Garmin Etrex) to allow for their visualization on the map. Data collection was conducted one week per month for 4 months. The prevalence was obtained based on the results of the serological tests.

Research ethics. The study was approved by the Comissão de Ética para Uso de Animais (Animal Ethics Committee) CEUA/UFV 02/2009 and by the Comitê de Ética em Pesquisa com Seres Humanos (Ethics in Human Research) 34/2009, Federal University of Viçosa - UFV. The application of the epidemiological questionnaires and sample collection were performed under the written consent of the responsible resident of each household sampled after presenting the proposal of the study to the owners, while highlighting the option of refusing participation.

Table 1. Number of farms and pigs sampled by rural communities

\begin{tabular}{lcc}
\hline Communities & Properties sampled (\%) & Pigs sampled \\
\hline 1óde Junho* & $19(39.5)$ & 70 \\
Águas da Prata* & $7(20.5)$ & 9 \\
Cachoeirinha* & $8(21)$ & 11 \\
Limeira* & $9(20.9)$ & 27 \\
Terra Prometida* & $13(35.1)$ & 35 \\
Alegre & $5(27.8)$ & 7 \\
Balaio & $3(30)$ & 3 \\
Bananal & $3(27.3)$ & 2 \\
Capivara & $5(22.7)$ & 14 \\
Divino do Sul & $8(28.6)$ & 26 \\
Itaúna & $7(30.4)$ & 15 \\
Queiroga & $2(28.6)$ & 4 \\
Traíra & $2(40)$ & 9 \\
Volta Grande & $10(25)$ & 15 \\
14 & $101(45)$ & 247 \\
\end{tabular}

* Agrarian Reform Settlement.
Collection of blood sample. In each sample farm, blood samples were collected of every pig over three months old in order to avoid false-positive results due to the passive immunity transferred to the piglets via milk. Porcine immunoglobulins are not transferred across the placenta, making colostrum the sole source of acquired antibodies and the antibodies persist in the milk for a period of up to two months (Garcia \& Del Brutto, 2000). Blood samples were taken from the orbital plexus of the pigs with approximately $10 \mathrm{ml}$ of blood being collected from each animal. Serum was obtained at room temperature and then it was frozen and stored at $-20^{\circ} \mathrm{C}$ until processing. The pig population consisted of crossbred pigs and pigs of a non-defined breed raised in rustic conditions.

Laboratory analysis. The indirect ELISA test was used as a preliminary screening method to select for possibly positive cases in pigs. Samples that were positive were subjected to a Western Blot analysis which provided a conclusive diagnosis. For the serological tests, the heterologous total antigen of Taenia crassiceps was used, according to the methodology described below.

ELISA. Polystyrene sensitized plates were used with antigen diluted in carbonate-bicarbonate buffer $0.5 \mathrm{M} \mathrm{pH} 9.6$ for 12 hours at $4^{\circ} \mathrm{C}$, preceded by incubation at room temperature for one hour. After washing in saline solution containing $0.05 \%$ Tween-20, the reactive sites were blocked with $5 \%$ skimmed milk in PBS pH 7.4 for 1 hour at $37^{\circ} \mathrm{C}$. New washes were performed and serum samples were diluted at 1:12.5 in 1\% skimmed milk in PBS pH 7.4, and the plate incubated for 30 minutes at $37^{\circ} \mathrm{C}$. After washing, the conjugate (peroxidase-labeled rabbit anti-pig IgG A-5670, Sigma Chemical Co., St. Louis, MO, USA) was diluted at 1:5000 and added, and the procedures of incubation and washing were repeated. The reaction was developed with OPD solution $\left(0.1 \%\right.$, Sigma P 8287 ) and $0.003 \% \mathrm{H}_{2} \mathrm{O}_{2}$ in $0.2 \mathrm{M}$ citrate phosphate buffer ( $\mathrm{pH}$ 5.0) during an incubation period of 5 minutes. The reaction was blocked with $4 \mathrm{~N}_{2} \mathrm{SO}_{4}$ and readings were conducted in a spectrophotometer at $492 \mathrm{~nm}$. The amount of reagents applied to each well of the plate was $100 \mu \mathrm{l}$, except that blocking was performed with $200 \mu$ l. In order to minimize the differences between the plates, facilitate comparison and provide a more accurate result, the cut-off point was calculated from the mean values of optical densities (OD) of negative controls on each plate plus two standard deviations (2SD). OD readings obtained were adjusted by the correction factor, which was calculated from the difference between the mean of the negative and the positive controls of the standard plate, divided by the difference between the mean of the negative and the positive controls of the test plate.

Western blot. After electrophoresis, the selective peptides for the diagnosis were separated by SDS-PAGE and transferred from gel to nitrocellulose membranes 0,2 (Millipore, USA) according to the method described by Towbin et al. (1979), using transfer buffer solution containing methanol (25mM Tris-hidroximetilaminoetano; $192 \mathrm{~mm}$ glycine and 20\% methanol -v/v-, pH 8.3). The transfer was performed for a period of 1 hour at room temperature with current of $50 \mathrm{~mA}$ and constant voltage of $17 \mathrm{~V}$ (Bio-Rad Laboratories, Hercules, CA, USA). After transfer, the nitrocellulose membranes were stained with Ponceau-S 0.5\% aqueous solution, for qualitative and quantitative viewing of the transfer. Strips of 3 to $4 \mathrm{~mm}$ width were obtained from the membranes, and they were bleached and washed three times in saline $(0.15 \mathrm{M}$ $\mathrm{NaCl})$ containing $0.05 \%(\mathrm{v} / \mathrm{v})$ Tween-20. The strips were treated with blocking solution of $5 \%$ skim milk dissolved in Tris-saline (10 mM Tris-hydroxymethyl aminomethane) and $0.15 \mathrm{M} \mathrm{NaCl}, \mathrm{pH}$ 7.4 , by heating to about $90{ }^{\circ} \mathrm{C}$ and filtering through filter paper for an hour under slow stirring at room temperature. Diluting solution was added to serum samples. Serum samples analyzed 
in a diluting solution (blocking solution diluted $1 / 5$ in Tris-saline) were diluted at 1:100 and added to the strips, and incubation was performed for $14-18$ hours at $4^{\circ} \mathrm{C}$ under slow stirring. After six 5-min washes, the strips were again incubated for one hour with the conjugate (peroxidase-labeled rabbit anti-pig IgG A-5670, Sigma Chemical Co., St. Louis, MO, USA), suitably diluted at 1:1000, and then new washes were performed. The peptides were evidenced as reactive with the chromogen solution $(5 \mathrm{mg}$ diaminobenzidine, $1.5 \% \mathrm{H}_{2} \mathrm{O}_{2}$ in PBS $\mathrm{pH} 7.2$ ) for about 10 minutes. Then, the strips were rinsed with distilled water and dried. Those peptides were analyzed by scanning densitometer GS-700 and the PM was calculated with the aid of software Quantity One, Version 1.4 (Bio-Rad). The seropositivity or seronegativity was based on whether or not a reaction occurred in the aforementioned peptides. The molecular weight markers used ranged from about $205 \mathrm{kD}$ to $6.5 \mathrm{kD}$ (Sigma M-4038). For the test, the total antigen of Taenia crassiceps was used at a concentration of $6 \mu \mathrm{g} / \mathrm{ml}$ (Pinto et al. 2001).

Assessment of risk factors. An epidemiological survey was conducted using a structured questionnaire containing closed and open-ended questions that had been previously tested. The whole questionnaire was administered by the same interviewer with each household owner to allow determination of the risk factors associated with taeniosis and cysticercosis. Information was collected about the household, sanitary infrastructure, food habits of the family, consumption of pork, source of water for human and animal drinking, husbandry system, animal management, knowledge about this zoonotic disease and family income. The interview was conducted informally, usually after the collection of the blood samples from the pigs.

Statistical analysis. The serological results and questionnaire responses were entered into a database that was created using software EpiInfo 3.5.1 (CDC 2008). Quality control measures were used to reduce the possibility of errors and ensure greater reliability of the data collected. With the results of the laboratory analysis, descriptive statistical analyses were conducted to determine the frequency of cysticercosis at the households and in the communities and populations sampled. The households were considered positive when at least one pig with cysticercosis was detected. To verify the association between the independent and dependent variables, we used the $\mathrm{X}^{2}$ (chi-squared) test and Fisher's exact test, with a significance level for rejection of the null hypothesis equal to $5 \%$. Odds ratio estimates were also obtained with a reliability interval of $95 \%$, adopting the value of 1 as the basis category for determining the risk factors.

\section{RESULTS}

A total of 247 pigs were examined at 101 (45\%) farms. In each community a minimum of $20 \%$ of farms was sampled (Table 1). Prevalence of porcine cysticercosis was $5.3 \%$ (13/247), and positive pigs were found in 10 of the farms sampled $(9.9 \%)$. The number of pigs with cysticercosis in each infected household ranged from 1 up to 3 . Cysticercosis was present in $21 \%(3 / 14)$ of the rural communities and $60 \%(3 / 5)$ of the settlements of the county. Most of the pigs sampled (61\%) were raised by Agrarian Reform settler families on small farms (Family Production UnitsFPU) with an average of 2.4 pigs per farm and 39\% raised by medium or large landowners, with an average of 1.9 pigs per farm. The mean age of pigs was 11 months, ranging between 3 months and 36 months. Prevalence of porcine cysticercosis by age was $11.76 \%(2 / 17)$ for 3 months, $3.44 \%$ $(1 / 29)$ for 4 months, $4.87 \%(2 / 41)$ for 8 months, $6.52 \%$
(3/46) for 12 months, $13 \%$ (3/23) for 24 months and $16 \%$ (1/6) for 36 months, respectively. For the other age groups (5, 10 and 30 months), no positive cases were found. Out of the 13 seropositive pigs, 7 were females and 6 were males. Seropositivity was $18.5 \%$ (7/135) for females and 5.53\% (6/112) for males. All the positive farms belonged to Agrarian Reform settlements represented by three different communities. The community with the highest prevalence was "Limeira" with $44.4 \%$ (4/9) of the positive farms and a prevalence of cysticercosis of $22.2 \%(6 / 27)$, followed by "Terra Prometida" with 23\% (3/13) of the positive farms and a prevalence of $11.4 \%(4 / 35)$, and the community " 1 o de Junho" with $16 \%$ (3/19) of the positive farms and $4.3 \%$ $(3 / 70)$ of the cases of porcine cysticercosis (Table 2). The seroprevalence obtained by ELISA was $17 \%$ and by the Western Blot was 5.3\% (13/247). From the total farms that raised pigs exclusively in pens $2.6 \%(2 / 76)$ had seropositive cases, and from those that raised pigs in unconfined environments the prevalence was 32\% (8/25). From the total of free-ranging pigs $33.3 \%(11 / 33)$ were cysticercosis positive.

For the risk factors, from 101 farms, $75 \%$ raised the pigs confined in pens at all stages of life and $25 \%$ raised the pigs in unconfined conditions. As for the destination of human faeces, the farms sampled had three possibilities: cesspit $(41.5 \%)$, outdoors $(28.8 \%)$ and stream $(29.7 \%)$. In total, $27.5 \%(8 / 29)$ of the farms where faeces had been left in the environmental, and only $4.7 \%$ of the of those whose destination was a cesspit were positive for porcine cysticercosis. It was further noticed that households whose destination of faeces was in fields or open areas have a 7.6 times higher chance to have porcine cysticercosis than those whose destination is the cesspit ( $\mathrm{p}=0.01$ ) (Table 3). Among the sampled farms, $83 \%$ provide food scraps for pigs. All households that were positive for cysticercosis provided slops. No cases of cysticercosis were found in households that do not provide slops for the pigs. There was no statistically significant association between the occurrence of porcine cysticercosis and income, though it was observe that $75.2 \%$ of the farms receiving less than a minimum wage and $19 \%$ of those re-

Table 2. Seropositivity for porcine cysticercosis by number of farm and number of pig samples analyzed

\begin{tabular}{lcc}
\hline Communities & $\begin{array}{c}\text { Farms with seropositive } \\
\text { pigs (\%) }\end{array}$ & $\begin{array}{c}\text { Seropositives } \\
\text { pigs (\%) }\end{array}$ \\
\hline 1o de Junho* & $3(16)$ & $3(4)$ \\
Águas da Prata* & - & - \\
Cachoeirinha* & - & - \\
Limeira* & $4(44)$ & $6(22)$ \\
Terra Prometida* & $3(23)$ & $4(11)$ \\
Alegre & - & - \\
Balaio & - & - \\
Bananal & - & - \\
Capivara & - & - \\
Divino do Sul & - & - \\
Itaúna & - & - \\
Queiroga & - & - \\
Traíra & - & - \\
Volta Grande & - & - \\
TOTAL & 10 & 13
\end{tabular}

* Agrarian Reform Settlement. 
Table 3. Analysis of the potential risk factors associated with the occurrence of porcine cysticercosis

\begin{tabular}{lccc}
\hline Risk factors & Odds Ratio & IC $95 \%$ & P \\
\hline $\begin{array}{l}\text { Pigs management system } \\
\text { Confined in pens }\end{array}$ & 1 & - & \\
$\begin{array}{l}\text { Raise at large } \\
\text { Destination of human faeces }\end{array}$ & 17.4 & $3-131$ & 0.0001 \\
Cesspit & 1 & & \\
Outdoors & 7.6 & $1.3-57.5$ & - \\
Water for animal consumption & & & 0.012 \\
Treated water & 1 & - & - \\
Cistern & 1.7 & $0.0-77$ & 1.0 \\
Spring & 1.3 & $0.0-58$ & 1.0 \\
River & 1.3 & $0.14-32.5$ & 1.0 \\
Family income & & & \\
Less than a basic salary & 1 & - & - \\
More than a basic salary & 23 & $0.26-52.1$ & 0.68 \\
knowledge about cysticercosis & & & - \\
Yes & 1 & - & 1.00 \\
No & 0.9 & $0.20-4.01$ & - \\
Age & & & - \\
Between 3 and 6 months & 1 & - & - \\
Up to 6 months & 2.9 & $0.58-16.2$ & 0.15 \\
Sex & & & - \\
Male & 1 & $0.28-3.36$ & 0.95 \\
Female & 0.97 &
\end{tabular}

ceiving one to three minimum wage incomes were positive for porcine cysticercosis. Regarding the source of water for animal consumption, $69.3 \%$ of the sampled farms used water from a stream, $12.8 \%$ used treated water, $9.9 \%$ used water from a spring, and $7.9 \%$ used water from a cistern.

\section{DISCUSSION}

The high prevalence of porcine cysticercosis founded (5.3\%) call attention for the importance of this zoonotic parasite disease in rural communities of the Eastern Minas Gerais State. Most of the pigs sampled (61\%) were raised by Agrarian Reform settler families on FPU with an the slightly higher average number of pigs raised per settlement than the other types of properties may be associated with the need for production for consumption by the settlers and their families, a typical feature in the region. It should be noted that cysticercosis was also found in pigs raised exclusively under confinement. This may be associated with the supply of food contamined with Taenia solium eggs as result of inadequate handling of food by tapeworm carriers. However, it was found that the pigs raised at large were 17 times more likely to become seropositive for cysticercosis than those that were always kept confined ( $p=0.0001)$, which is an expected result since animals raised at large are exposed to several risk factors. This result is similar the finding by Lescano et al. (2007) and Deckers \& Dorny (2010), who reported higher prevalence rates in pigs raised at large and noted that these animals' habit of coprophagia favours infection because of the ingestion of faeces containing eggs or proglottids from tapeworm carriers. The management system of the pigs and the destination of human faeces were found to be crucial in the variation of seropositivity, with statistically significant differences $(p<0.05)$. Also, regard to sewage disposal, the difference between cesspit and environmental variables was significant $(\mathrm{p}=0.01)$ and supports the premise that the endemicity of cysticercosis is associated with the lack of adequate sanitary infrastructure (Sikasunge et al. 2007). These facts supports the idea that changes in the sanitation system can prevent new infections and allow control of the CT complex. Gottschalk et al. (2006) noted that humans are responsible for the dissemination of eggs in the environment, and the presence of cesspits in rural areas can prevent contact between animals and contaminated human faeces, thus preventing infection. A non-statistically significant association between the occurrence of cysticercosis and the source of water for pigs. Nevertheless, it was observed that prevalence among farms with positive cases was higher among those whose water was obtained from a stream, $10 \%(7 / 70)$. This observation may be associated with the lack of adequate disposal of human waste and that incurs pollution and contamination of waterways with parasite eggs.

The FPU made up $56.4 \%$ of the sampled farms, and $43.6 \%$ consisted in estates or large farms. It was found that all farms with seropositive pigs were FPUs. These areas have a large concentration of people, unlike the other types of farms. Our result is consistent with the findings of Phiri et al. (2003), who reported a correlation of porcine cysticercosis with the presence of high human density. Because both pigs and humans are responsible for maintaining the zoonotic cycle of Taenia solium (Flisser et al. 2003), the high animal and human concentration observed in the settlements might favour the occurrence and maintenance of the complex in these areas.

With regard to knowledge about cysticercosis, there was no association with infection positivity $(\mathrm{p}=1.0)$. Most respondents reported knowing how to identify both the tapeworm and cysticercosis. However, despite the reported knowledge, we noticed clear the absence of information on the paths of infection and transmission of disease. This lack of knowledge may contribute to the persistence of porcine cysticercosis at households (Jayashi et al. 2012). Ferreira et al. (2012) observed that the lack of knowledge significantly favours the occurrence of porcine cysticercosis. Also it has been shown that knowledge of the disease contributed to the reduction of infection rates in human populations in endemic areas (Mwape et al. 2013).

Regarding the age of the animals, no statistically significant difference was found when comparing pigs from 3 to 6 months of age to those more than 6 months old ( $p>0.05$ ). This result does not corroborate what was expected, nor is it consistent with what was reported by Gottschalk et al. (2006), who noted that for animals raised at large and in places where human faeces is disposed of in the open, the older the pigs, the greater the likelihood of infection due to the longer exposure to the parasite. Likewise, there was no relationship between gender and cysticercosis, and prevalence was estimated at $10.5 \%$ for males and $12 \%$ for females.

The presence of cysticercosis only in the settlements seems to be associated with the lack of adequate infrastructure for the disposal of human waste and the presence of free ranging pigs. Settlements has greater agglomeration of families (Brazil has 1,288,444 settled families), greater number of pigs raised by these families, and the absence 
of in-depth awareness-raising education regarding both contamination and transmission TC to humans and to pigs. This result are similar to previous studies, indicating that the natural dynamic of cysticercosis infection in pigs may be facilitated by high rates of environmental contamination (Mwape et al. 2013), and the presence of the tapeworm carrier at household level (Lescano et al. 2007). These settlements areas may have higher number of porcine cysticercosis than the prevalence found and it probably happens because the high number turning seronegative within a year after infection hiding an important number of infections (Mwape et al. 2013).

The study revealed endemics communities for porcine cysticercosis represented by the Agrarian Reform settlements. Based on these results, factors such as raising pigs in confinement, adequacy of rural sanitation, public access to information about this zoonosis (mainly regarding the mode of infection and preventive measures), faecal examination of the population and treatment tapeworm carriers are recommended measures to tackle this important agricultural and public health disease in the positive communities. Awareness of TC among medical doctors, veterinarians, family farmers and the public should be developed through appropriate information and education. In addition, because the huge number of settlements in Brazil, where thousands of families are living in similar conditions, these findings draws attention to the need for additional studies to evaluate the epidemiological situation of taeniosis cysticercosis complex in these areas.

Acknowlegements.- We are grateful to Conselho Nacional de Desenvolvimento Científico e Tecnológico (CNPq) and Fundação de Amparo à Pesquisa do Estado de Minas Gerais (FAPEMIG) for financial support for this study. We are sincerely grateful for the technicians and lab workers who combat endemic diseases in the county of Tumiritinga, Minas Gerais, Brazil. Thankful to Vickie Ramirez, research coordinate, and Michael Park, for Center for One Health research in the Department of Environmental and Occupational Health Sciences of the University of Washington, WA, USA, for the English review.

\section{REFERENCES}

CDC 2008. EpiInfo Database and statistics software for public health professionals. Version 3.5.1. Centers for Diseases Control and Prevention.

Deckers N. \& Dorny P. 2010. Immunodiagnosis of Taenia solium taeniosis/ cisticercosis. Trends Parasitol. 26(3):137-144.

Ferreira P.S., Acevedo-Nieto E.C., Santos T.O., Peixoto R.P.M.G., Silva T.O., Fellipe A.G., Pinto P.S.A. \& Caldi J.F.B. 2012. Prevalence of the taeniosis-cysticercosis complex in rural areas from Matias Barbosa, Minas Gerais State, Brazil (In Portuguese). Semina, Ciênc. Agrárias 33(6):2307-2314.

Flisser A., Sarti E., Lighowlers M. \& Schantz P. 2003. Neurocysticercosis: regional status, epidemiology, impact and control measures in the Americas. Acta Trop. 87:43-51.

Flisser A. \& Gyorkos T.W. 2007. Contribution of immunodiagnostic tests to epidemiological intervention studies of cysticercosis/taeniosis in México. Parasite Immunol. 29:637-49.

Garcia H.H. \& Del Brutto 0.H. 2000. Taenia solium cysticercosis. Infect. Dis. Clin. N. Am. 14(1):97-119.

Gonzalez A.E., Lopez-Urbina T., Tsang B., Gavidia C., Garcia H.H., Silva M.E., Ramos D.D., Manzanedo R., Sanchez-Hidalgo L., Gilman R.H., Tsang V.C. \& Cysticersosis working group in Peru 2006. Transmission dynamics of Taenia solium and potential for pig-to-pig transmission. Parasitol. Int. 55:131-35.
Gottschalk S., Buzi K.A., Galindo L.A., Abreu B.X., Nunes C.M. \& Biondi G.F. 2006. Soroprevalência e aspectos epidemiológicos da cisticercose suína em criações de "fundo de quintal" na microrregião de Registro/SP. Vet. Zootec. 13(12):1192-200.

Iasbik A.F., Pinto P.S.A., Bevilacqua P.D., Nero L.A., Santos T.O. \& Felippe A.G. 2010. Prevalência do complexo teníase-cisticercose na zona rural do município de Viçosa, Minas Gerais. Ciência Rural 40(7):1664-1667.

IBGE 2008. Produção da Pecuária Municipal 2007. Instituto Brasileiro de Geografia e Estatística. Available at <http://www.ibge.gov.br/cidadesat> Accessed on Aug. 2009.

IMA 2010. Cadastro dos estabelecimentos rurais com produção agropecuária do município de Tumiritinga, Minas Gerais. Instituto Mineiro de Agropecuária. <http://www.ima.mg.gov.br> Accessed on Mar. 2010.

INCRA 2010. SR06/Minas Gerais, Instituto Nacional de Colonização e Reforma Agraria. <http://www.incra.gov.br/reforma-agraria> Accessed on Mar. 2010.

Jayashi C.M., Arroyo G., Lightowlers M.W., Garcia H.H., Rodrigues S. \& Gonzales A.E. 2012. Seroprevalence and risck factors for Taenia solium cysticercosis in rural pigs of northern Peru. PLos Negl. Trop. Dis. 6(7):e1733.

Lescano A.G., Garcia H.H., Gilman M.C.G., Tsang V.C.W., Gavidia C.M., Rodriguez S., Moulton L.H., Green J.A. \& Gonzalez A.E. 2007. Swine cysticercosis hotspots surrounding Taenia solium tapeworm carriers. Am. J. Trop. Med. Hyg. 76(2):376-383.

Mwape K.E., Phiri I.K., Praet N., Speybroeck N., Muma J.B., Dorny P. \& Gabriel S. 2013. The incidence of human cysticercosis in a rural community of eastern Zambia. PLoS Negl. Trop. Dis. 7(3):e2142.

Ndimubanzi P.C., Carabin H., Budke C.M., Nguyen H., Qian Y.J., Rainwater E., Dickey M., Reynolds S. \& Stoner J.A. 2010. A systematic review of the frequency of neurocysticercosis with a focus on people with epilepsy. PLoS Negl. Trop. Dis. 4:e870.

Phiri I.K., Ngowi H., Aonso S., Mantenga E., Boa M., Mukaratirwa S., Githigia S., Saimo M., Sikasunge C., Maingi N., Lubega G.W., Kassuku A., Michael L., Siziya S., Krecek R.C., Noormahomed E., Vilhena M., Dorny P. \& Willingham A.L. 2003. The emergence of Taenia solium cysticercosis in Eastern and Southern Africa as a serious agricultural problem and public health risk. Acta Trop. 87:13-23.

Pinto P.S.A., Vaz A.J., Nakamura P.M. \& Germano P.M.L. 2001. Immunoblot analysis using antigen from Taenia cracisseps cysticerci in the diagnosis of pig cysticercosis. Boln Chil. Parasitol. 56:36-42.

Pinto P.S.A., Almeida L.P., Germano P.M.L., Vaz A.J. \& Nakamura P.M. 2002. Cysticercosis occurrence and sanitary risk in groups of inspected and not inspected pig in Brazil. Parasitol. Latinoam. 57(3/4):129-33.

Pondja A., Neves L., Mlangwa J., Afonso S., Fafetine J., Willinghan III A.L., Thamsborg S.M. \& Johansen M.V. 2010. Prevalence and risk factors of porcine cysticercosis in Angónia District, Mozambique. PLoS Negl. Trop. Dis. 4(2):1-5.

Santos T.O., Pinto P.S.A., Iasbik A.F., Silva L.F., Nieto E.C.A. \& Guimarães-Peixoto R.P.M. 2013. Epidemiological survey of the taeniasis/cysticercosis complex in cattle farms in Viçosa County, Minas Gerais, Brazil. Pesq. Vet. Bras. 33(4):449-452.

Sikasunge C.S., Phiri I.K., Phiri A.M., Dorny P. \& Siziya S. 2007. Risk factors associated whit porcine cysticercosis in selected districts of Eastern and Southern provinces of Zambia. Vet. Parasitol. 41:195-201.

Silva L.F., Pinto P.S.A., Ducas C.T.S., Santos T.O., Nieto E.C.A. \& Peixoto R.P.M.G. 2015. Relevant peptides of Taenia crassiceps for the diagnosis of bovine cysticercosis by immunoblot. Arq. Bras. Med. Vet. Zootec. 67(3):891-898.

Souza L., Almeida L.P. \& Carrijo K.F. 2013. 0 complexo teniase-cisticercose: indicadores de fatores de risco em propriedades rurais com criação artesanal de suínos em Uberlandia/MG. Vet. Notícias 19(1):23-29.

Torgerson P.R. \& Macpherson C.N. 2011. The socioeconomic burden of parasitic zoonoses: global trends. Vet. Parasitol. 82:79-95.

Towbin H., Staehelin T. \& Gordon I. 1979. Electrophoretic transfer of proteins from polyacrylamide gels to nitrocellulose sheets: procedure and some applications. Proc. Natl Acad. Sci. USA 76:4350-4354. 